\title{
Action of 1-Methylcyclopropene on Postharvest Conservation of Banana 'Prata-Anã' Gorutuba Clone
}

\author{
Flávia S. Aguiar ${ }^{1}$, Wlly P. A. Dias ${ }^{1}$, Thais C. Santos ${ }^{1}$, Juceliandy M. S. Pinheiro ${ }^{2}$, Gisele P. Mizobutsi ${ }^{1}$, \\ Ariane Castricini ${ }^{2}$, Sarah N. A. Fonseca ${ }^{1}$, Eliene A. Paraizo ${ }^{1}$, Raquel R. S. Sobral ${ }^{1}$ \& Simônica M. Oliveira ${ }^{1}$ \\ ${ }^{1}$ Department of Agricultural Sciences, Universidade Estadual de Montes Claros, Minas Gerais, Brazil \\ ${ }^{2}$ Empresa de Pesquisa Agropecuária de Minas Gerais (EPAMIG), Minas Gerais, Brazil \\ Correspondence: Flávia S. Aguiar, Department of Agricultural Sciences, Universidade Estadual de Montes \\ Claros, Av. Reinaldo Viana, Janaúba, MG, Brazil. E-mail: fsa.agronomia@gmail.com
}

Received: September 1, 2019

Accepted: September 3, 2020

Online Published: October 15, 2020

doi:10.5539/jas.v12n11p322

URL: https://doi.org/10.5539/jas.v12n11p322

\begin{abstract}
The banana is a highly perishable fruit in which storage and transport for a long period is limited due to the lack of post-harvest technologies that aim to retard fruit ripening. In this regard, the objective of this study was to evaluate the postharvest conservation period of the 'Prata-Anã' clone Gorutuba banana using different concentrations of 1-methylcyclopropene (1-MCP), associated with the modified atmosphere and refrigerated storage. Banana bunches (Musa spp. AAB) 'Prata-Anã' Gorutuba clone were obtained from Belém farm, located in Janaúba-MG. The pieces were decomposed in bouquets of 4 fruits and submitted to 1-MCP application at concentrations of 0.0 ; $0.2 ; 0.4 ; 0.6 ; 0.8$ and $1.0 \mathrm{ppm}$ for 24 hours and stored refrigerated at room temperature to $13 \pm 1{ }^{\circ} \mathrm{C}$. Every 5 days physical and chemical evaluations were performed. There was a delay in the ripening of fruits subjected to refrigeration and treated with $0.6 \mathrm{ppm}$ of 1-MCP and increase in shelf life, due to probable inhibition of ethylene, which showed firmer fruits. Respiratory activity decreased with increasing concentration of 1-MCP. In refrigerated storage, fruits treated with 1-MCP were kept longer than 30 days. For the fruits kept at room temperature shelf life was 21 days for fruit subjected to concentrations of 0.4 to $1.0 \mathrm{ppm}$. However, the use of 1-MCP associated with the modified atmosphere under refrigeration directly influenced the postharvest conservation of bananas, allowing a longer period of commercialization.
\end{abstract}

Keywords: Musa spp., 1-MCP, ripening

\section{Introduction}

The banana tree (Musa spp.) is one of the most cultivated tropical fruit trees in the world. Its cultivation extends to regions of humid climate like the semiarid regions. It is a fruit of great economic and social importance. However, the banana has a quick ripening after harvest with a relatively short shelf life, a high respiration rate, and a highly perishable fruit which limits storage and transportation to distant markets. To this end, the study of technologies that aim to increase postharvest conservation has been evaluated, in order to allow longer storage and transportation of bananas, allowing the production flow and reducing postharvest losses, offering quality products to the final consumer.

The main postharvest conservation techniques are based on the inhibition of ethylene action and reduction of respiratory activity. Among the inhibitors of ethylene action, 1-methylcyclopropene (1-MCP) stands out. 1-MCP is derived from cyclopropene and acts as an inhibitor of ethylene action by permanently binding to specific proteins in the cell membrane, preventing ethylene from sending congruent signals to maturity and senescence. However, the return of plant product sensitivity to ethylene may occur due to the formation of new receptor sites (Hall et al., 2000; Li et al., 2017).

The refrigerated storage and modified atmosphere are the main and most economical post-harvest preservation techniques and can be used to extend the useful life of plant products in general. The use of refrigeration reduces the climacteric respiration of the fruit by delaying the climatic peak, and consequently the ripening metabolism and the senescence of the fruits. Modified atmosphere can be understood as the presence of an artificial barrier to gas diffusion around the product, which results in a reduction in the level of $\mathrm{O}_{2}$, increased level of $\mathrm{CO}_{2}$, change in ethylene and water vapor concentration and changes in other volatile compounds (Lana \& Finger, 2000). 
According to Santos et al. (2011) the combination of modified atmosphere and low temperature and high relative humidity ensures the preservation of fresh fruits during transportation and storage for domestic market. However for foreign markets it is necessary to associate such techniques to others, aiming to extend the period of transport and storage, enabling exploration of new markets.

Therefore, to delay the ripening and prolong the shelf life of fruits, the associated use of 1-MCP with refrigerated storage and packaging has been evaluated as an alternative that allows the increase in exports and marketing of the product to more distant markets, reducing also the postharvest losses. In this regard, the objective of this study was to evaluate the postharvest conservation period of the 'Prata-Anã' banana, Gorutuba clone, using different concentrations of 1-methylcyclopropene, associated with the modified atmosphere and refrigerated storage.

\section{Material and Methods}

Bunches of banana (Musa spp. AAB) clone 'Prata-Anã' Gorutuba aged 17 weeks were obtained at Fazenda Belém, located at geographic coordinates: latitude $-15^{\circ} 44^{\prime} 45.3^{\prime \prime} \mathrm{S}$ and longitude $-43^{\circ} 18^{\prime} 40.8^{\prime \prime} \mathrm{W}$, in the municipality of Janaúba, Minas Gerais. The pieces were transported to the Postharvest Fruit Physiology Laboratory of the Montes Claros State University, Janaúba campus, where they were decomposed into four fruit bouquets. The fruits were then washed with water and $0.2 \%$ neutral detergent for latex coagulation and surface cleaning. Malformed, diseased or mechanically damaged fruits were selected and eliminated. Subsequently, the bouquets were immersed

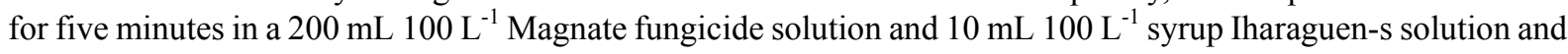
placed to air dry.

The fruits were placed in airtight plastic boxes of $0.50 \mathrm{~m}^{3}$ and submitted to concentrations of $0.0 ; 0.2 ; 0.4 ; 0.6 ; 0.8$; $1.0 \mathrm{ppm}$ of 1-methylcyclopropene (1 ppm of 1-MCP equivalent to $70.00 \mathrm{mg}$ of Mecypro 3.3\% i.a. in $1 \mathrm{~m}^{3}$ ), for 24 hours at an average temperature of $25 \pm 1^{\circ} \mathrm{C}$.

After 24 hours, the fruits were removed from the hermetic chambers, packed in low density polyethylene plastic bags $(16 \mu \mathrm{m})$ and placed in standard cardboard boxes for export of fruits, and stored in a cold chamber at $13 \pm 1^{\circ} \mathrm{C}$. and relative humidity of $85 \pm 5 \%$ for 30 days, and at intervals of five days, a part of the fruits was removed for the physical and chemical analysis, determining the shelf life of the fruits that remained in the refrigeration.

The experimental design was completely randomized (DIC), consisting of four replications, each repetition being a bouquet with four fruits, in a $6 \times 7$ factorial scheme, with six concentrations of $1-\mathrm{MCP}(0.0 ; 0.2 ; 0.4 ; 0.6 ; 0.8$ and $1.0 \mathrm{ppm})$ and seven periods of refrigerated storage $(0,5,10,15,20,25$ and 30 days).

The bananas subjected to 1 -MCP treatment were also stored at room temperature at $25^{\circ} \mathrm{C}$ without packaging to determine shelf life, being considered a second experiment.

The experimental design of the second experiment was completely randomized (DIC), consisting of four repetitions and each repetition a bouquet with four fruits, being the treatments six concentrations of 1-MCP $(0.0$; $0.2 ; 0.4 ; 0.6 ; 0.8$ and $1.0 \mathrm{ppm})$.

The fruit firmness was evaluated using a Brookfield CT3 $10 \mathrm{KG}$ digital texturometer. Measurements were made in the median region of the fruit, determined by the penetration force, measured in Newton $(\mathrm{N})$. The loss of fresh fruit mass was determined by the difference in fruit mass accumulated during the course of the experiment, considering the difference between the initial fruit mass and that obtained in each sampling period, the result being expressed as a percentage $(\%)$.

The pericarp color analysis was performed using a Color Flex 45/0 (2200), stdzMode: $45 / 0$ colorimeter with direct reflectance reading of the L* (luminance) $\mathrm{a}^{*}$ (red or green tint) and $\mathrm{b}^{*}$ (Hunterlab Universal Software system, measured in the middle region of the fruit. From the values of $\mathrm{a}^{*}$ and $\mathrm{b}^{*}$, the hue angle $\left({ }^{\circ} \mathrm{h}^{*}\right)$ and the chroma saturation index were calculated $\left(\mathrm{C}^{*}\right)$.

The shelf life was determined by fruit acceptance, as a function of appearance, during cold storage and at room temperature. The end of shelf life was determined when the fruit showed signs of deterioration, ie, stage 6 on the Von Loesecke visual maturity scale (CEAGESP, 2006). The shelf life count was determined in days of conservation.

The respiratory rate was determined by the titration method, according to Crispim et al. (1994) adapted by Deliza et al. (2008) and the results expressed in $\mathrm{mg} \mathrm{CO}_{2} \mathrm{~kg}^{-1} \mathrm{~h}^{-1}$ every assessment day. The percentage of $\mathrm{CO}_{2}$ was determined by direct measurement using a MOCOM brand carbon dioxide $\left(\mathrm{CO}_{2}\right)$ meter during the entire cold storage period.

For the analysis of soluble solids, titratable acidity and $\mathrm{pH}$, samples composed of four ground fruits were used. The determination of soluble solids was performed by refractometry, using ABBE benchtop refractometer, with 
reading in the range 0 to $95{ }^{\circ} \mathrm{Brix}$ and the results were expressed in ${ }^{\circ} \mathrm{Brix}$. The acidity was determined by titration, and the results expressed in grams of malic acid per $100 \mathrm{~g}$ of sample. $\mathrm{pH}$ was determined in bench size (IAL, 2008).

Data were subjected to analysis of variance and, through the F test, the significance of interactions between the factors tested was verified, with subsequent unfolding for significant results. The polynomial regression models were adjusted and the significant models of higher degree that best explain the biological phenomenon were selected. Respiratory activity and shelf life analyzes were performed using descriptive statistics analyzes.

\section{Results and Discussion}

The interaction, 1-MCP concentration and storage period, provided significant effect $(p<0.05)$ for the variables under study, except for fresh mass loss and $\mathrm{CO}_{2}$ concentration, where the effect for the factors under study are independents.

The firmness of the fruit (Figure 1A) showed a significant interaction between the study of the 1-MCP concentration and storage period, it was observed that the fruit had become stronger with increasing concentration of 1-MCP to approximately concentration of $0.65 \mathrm{ppm}$, where a maximum firmness of $46.4 \mathrm{~N}$ is found near day 5 of storage. At 30 days of refrigerated storage the fruits presented average firmness of $45.9 \mathrm{~N}$ for the concentration of o, $65 \mathrm{ppm}$ and $24.55 \mathrm{~N}$ for the fruits without the use of 1-MCP. These results highlight the effects of 1-MCP related to cell wall metabolism in fruits with reduced activity of the enzymes polygalacturonase, pectinamethylesterase and endo- $\beta$-1,4-glucanase (Watkins, 2006). Similar results were observed by Yan et al. (2011) on bananas and by Ohashis et al. (2016) on papaya 'solo'.

The fresh mass loss had an isolated effect only for the days storage factor (Figure 1B). There is an increase in fresh fruit loss regardless of the 1-MCP concentration for all storage days, reaching $1.69 \%$ on the 30th day of refrigerated storage. Mass loss is related to water loss, the main cause of deterioration, as it results not only in quantitative losses, but also in appearance (wilting), textural qualities and nutritional quality (Kader, 1992). According to M. I. F. Chitarra and A. B. Chitarra (2005) the rate of water that can be lost without deterioration varies for each vegetable, and should not exceed $10 \%$.

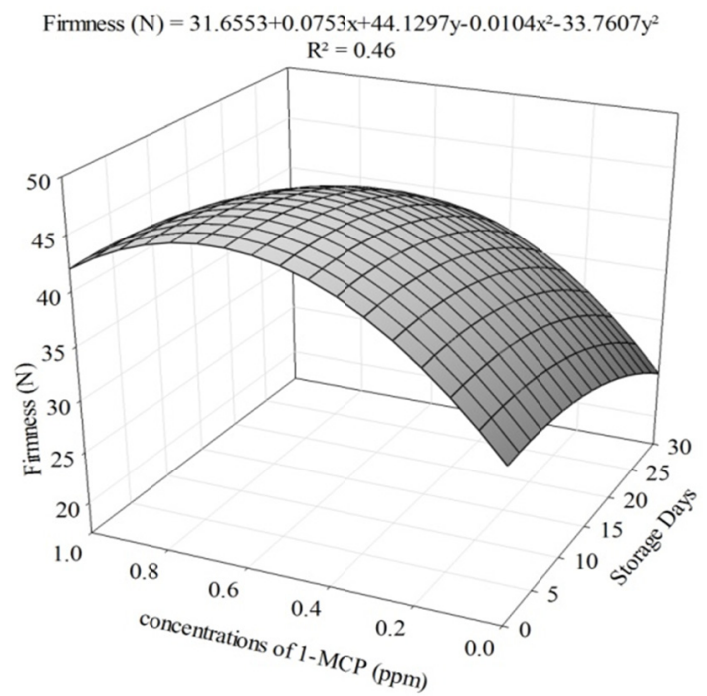

A

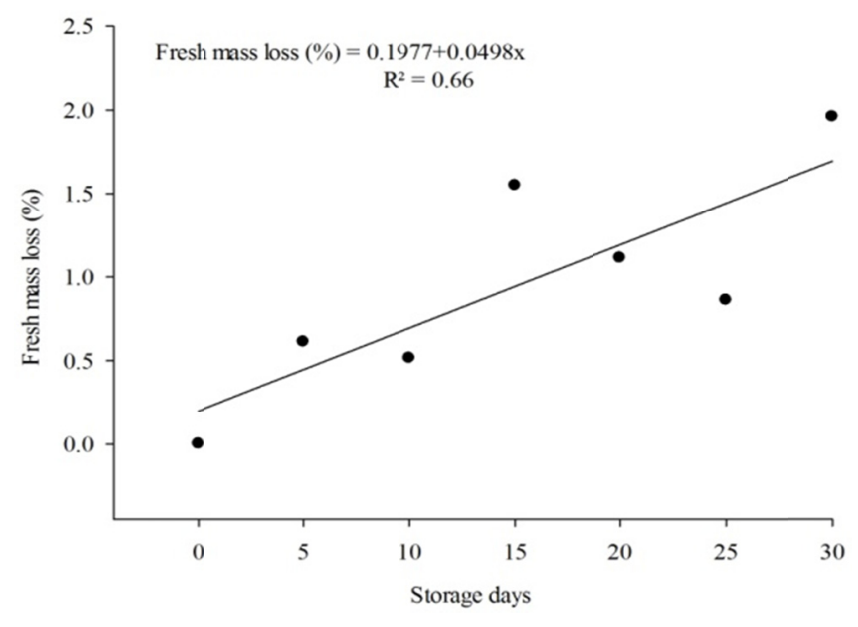

B

Figure 1. Firmness (A) and fresh mass loss (B) in banana 'Prata-Anã' clone Gorutuba submitted to different concentrations of $1-\mathrm{MCP}$ and stored at $13 \pm 1{ }^{\circ} \mathrm{C}$ and $85 \pm 5.0 \%$ of UR

For the hue angle (Figure 2) we note the interactive effect between the factors studied. It is observed that the point where it obtained the maximum was approximately in the concentration of $0.7 \mathrm{ppm}$ where it was observed $109.08{ }^{\circ}$ hue at the beginning of the storage. On the thirtieth day of refrigerated storage, values close to $101{ }^{\circ}$ hue were observed for fruits submitted to different concentrations of 1-MCP, indicating that fruits at 30 days of storage were green in color. In contrast, fruits without the use of 1-MCP showed values close to $92{ }^{\circ}$ hue indicating fruits 
with yellow color. These results are due to the effect of 1-MCP in delaying the chlorophyll degradation process by blocking the action of ethylene.

According to Brackmann et al. (2006), the presence of 1-MCP competes with ethylene for its receptor binding site, reducing its action on the mechanisms of synthesis and action of the enzymes responsible for the degradation of chlorophylls. Pre-existence of carotenoid pigments (yellow to orange color) while synthesis of other pigments is performed at relatively low levels (Silva et al., 2006).

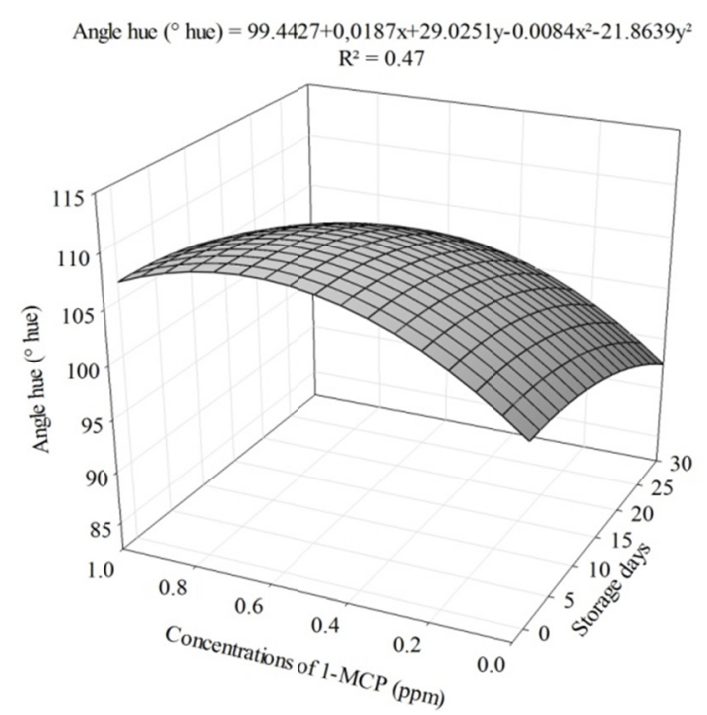

Figure 2. Angle hue ( ${ }^{\circ}$ hue) in 'Silver-Dwarf' banana clone Gorutuba subjected to different concentrations of $1-\mathrm{MCP}$ and stored at $13 \pm 1{ }^{\circ} \mathrm{C}$ and $85 \pm 5.0 \%$ of UR

For luminosity (Figure 3A) and chromaticity (Figure 3B) there is a significant interaction of the studied factors. Note that with the increase of 1-MCP concentration, a reduction in values up to approximately $0.7 \mathrm{ppm}$ was observed, with values of 44.7 and 33.8 near the tenth day of storage for light and light chromaticity respectively. However, with the days of storage, there was an increase in brightness and chromaticity, indicating fruits with more intense color and brighter after 30 days of refrigerated storage, being more attractive fruits.

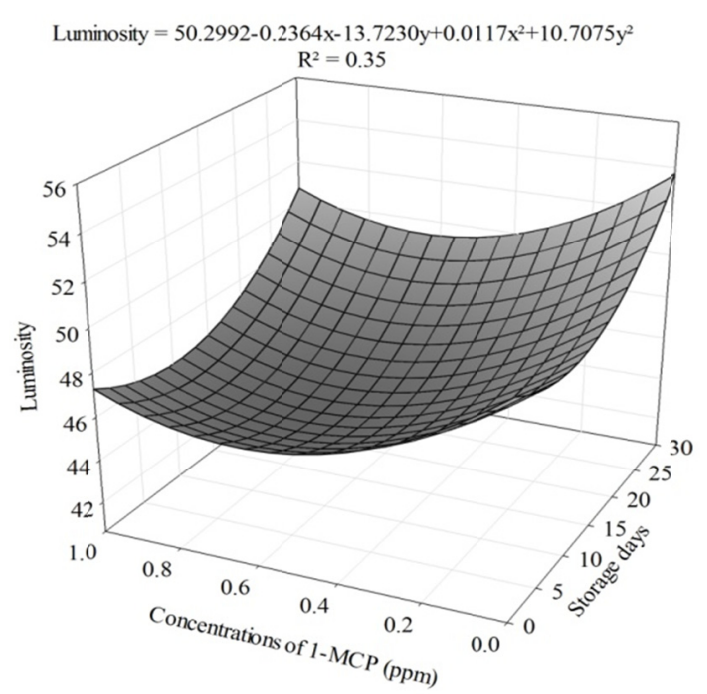

A

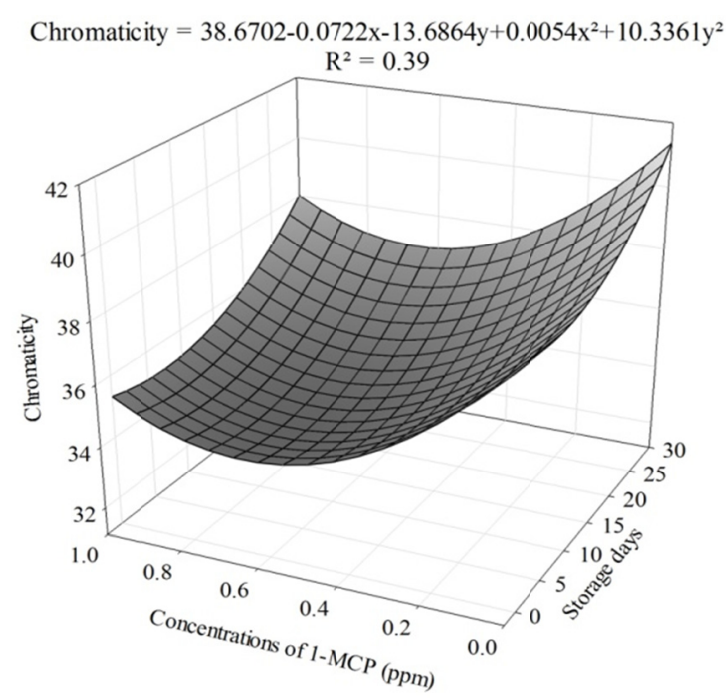

B

Figure 3. Luminosity (A) and chromaticity (B) in 'Prata-Anã' banana Gorutuba clone submitted to 1-MCP and stored at $13 \pm 1{ }^{\circ} \mathrm{C}$ and $85 \pm 5.0 \%$ of UR 
In general, the use of 1-MCP reduced the respiratory activity of fruits (Figure 4). Note that fruits without 1-MCP application presented climatic peak on the twenty-fifth day of storage, where values of $90.11 \mathrm{mg} \mathrm{CO} \mathrm{kg}^{-1} \mathrm{~h}^{-1}$. These results show the passage from the pre-climacteric to the climacteric period, in which the most pronounced changes occur in fruit ripening. For fruits subjected to a concentration of $0.2 \mathrm{ppm}$, respiratory elevation was observed $57.77 \mathrm{mg} \mathrm{CO}_{2} \mathrm{~kg}^{-1} \mathrm{~h}^{-1}$. However, the fruits subjected to concentrations of $0.4 ; 0.6 ; 0.8$ and $1.0 \mathrm{ppm}$ of 1-MCP showed no clear climatic peak. Possibly the reduction in the respiratory activity of fruits treated with $1-\mathrm{MCP}$ is due to the reduction in several stages of the respiratory process, such as glycolysis and tricarboxylic acid cycle (TCA) (Araújo et al., 2011).

Our results corroborate with Pinheiro (2007), who reports that 1-MCP delays the onset of respiratory ascension and also influences the magnitude of the process, decreasing the respiratory rate during the ripening process, probably due to the inhibition of some enzymes respiratory metabolism. Similar results with 1-MCP application on banana were also reported by Baez-Sañudo et al. (2009).

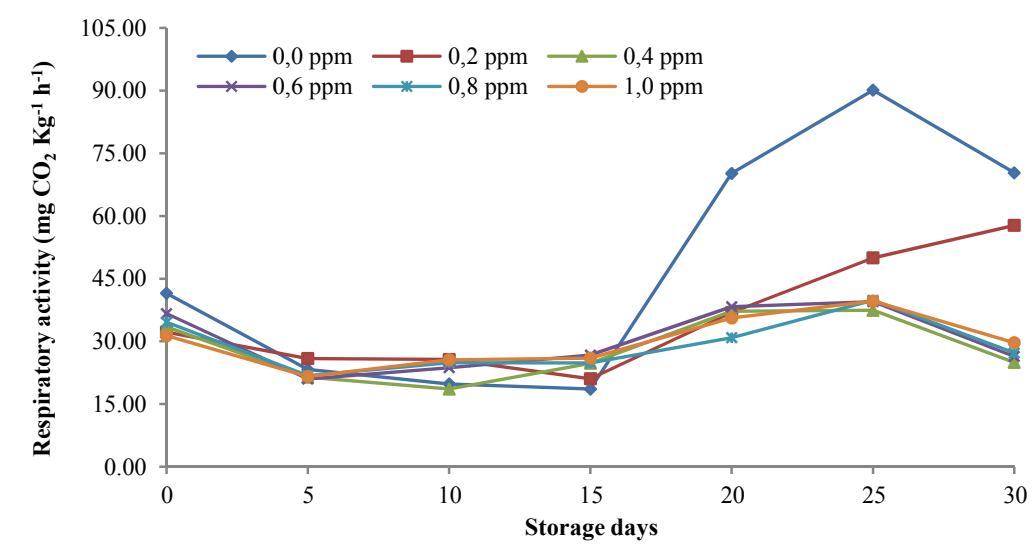

Figure 4. Respiratory activity of 'Prata-Anã' clone Gorutuba banana submitted to different concentrations of 1 -MCP and stored at $13 \pm 1{ }^{\circ} \mathrm{C}$ and $85 \pm 5.0 \%$ of UR

According to Figure 5A, it is observed that the concentration of $\mathrm{CO}_{2}$ inside the package decreased with the increase of 1-MCP concentration, this result shows the reduction of fruit respiration, due to the probable inhibition of ethylene, responsible hormone for controlling and coordinating a series of reactions and transformations in plant tissues, including respiratory metabolism.

However, analyzing the concentration of $\mathrm{CO}_{2}$ as a function of the days of refrigerated storage (Figure 5B), it can be noted that regardless of the concentration of 1-MCP, there was an increase in the concentration of $\mathrm{CO}_{2}$ over the days of refrigerated storage, showing an increase in respiratory rate of the fruits. These results are positive for the use of 1-MCP, since even inhibiting ethylene, at some point the fruit has to mature to be consumed.

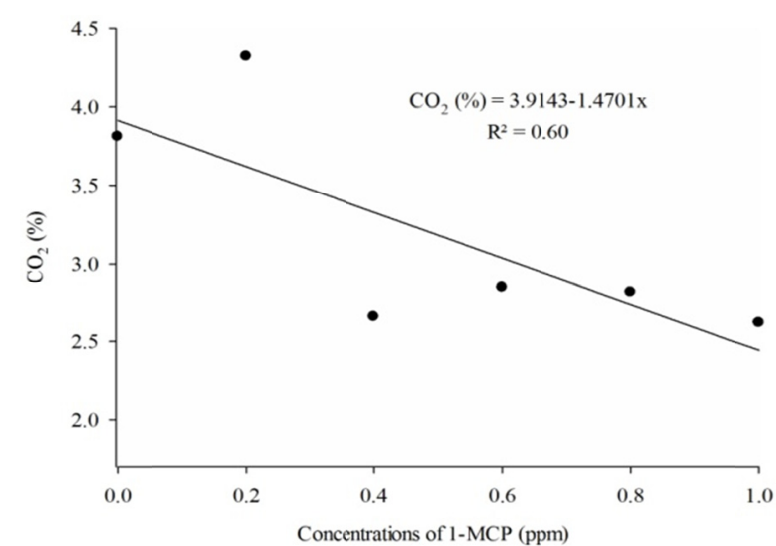

A

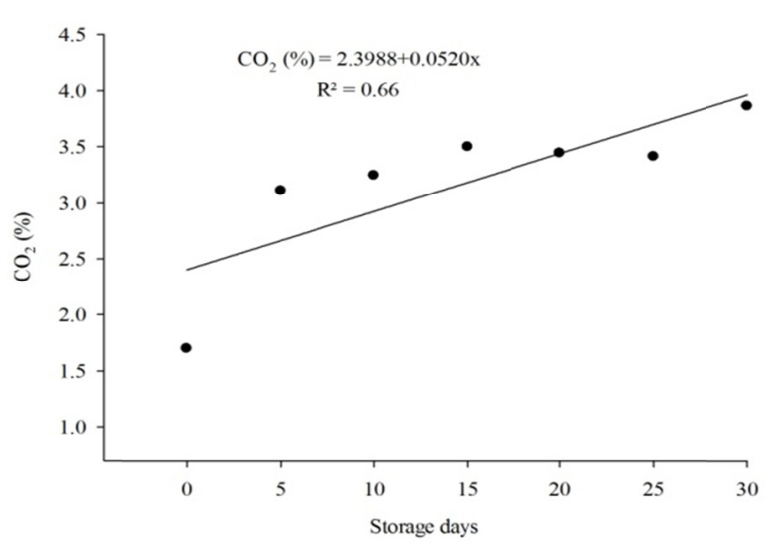

B

Figure 5. $\mathrm{CO}_{2}$ concentration in banana 'Prata-Anã' clone Gorutuba submitted to different concentrations of 1-MCP and stored a $13 \pm 1{ }^{\circ} \mathrm{C}$ and $85 \pm 5.0 \%$ of UR 
In Figure 6, for the soluble solids content, there was interaction between the factors storage days and the concentration of 1-MCP. It was verified that for storage days there was a linear increase in soluble solids content, and for 1-MCP concentrations the behavior was different. It is noted that with the increase of 1-MCP concentration occurred the reduction of soluble solids to the concentration of $0,6 \mathrm{ppm}$ for all storage days, where the lowest values were observed. However, it is observed that for storage days there is an increase in soluble solids content, and this increase is important not to affect the taste.

Thus, it can show positive results for the use of 1-MCP in the postharvest conservation of fruits, where it can be verified that the product acted in order to delay the fruit ripening, probably by blocking the action of ethylene, delaying the onset of the process of chemical transformations. The soluble solids content indicates the amount in grams of solids dissolved in the fruit pulp, corresponding to all substances dissolved in water (M. I. F. Chitarra \& A. B. Chitarra, 2005).

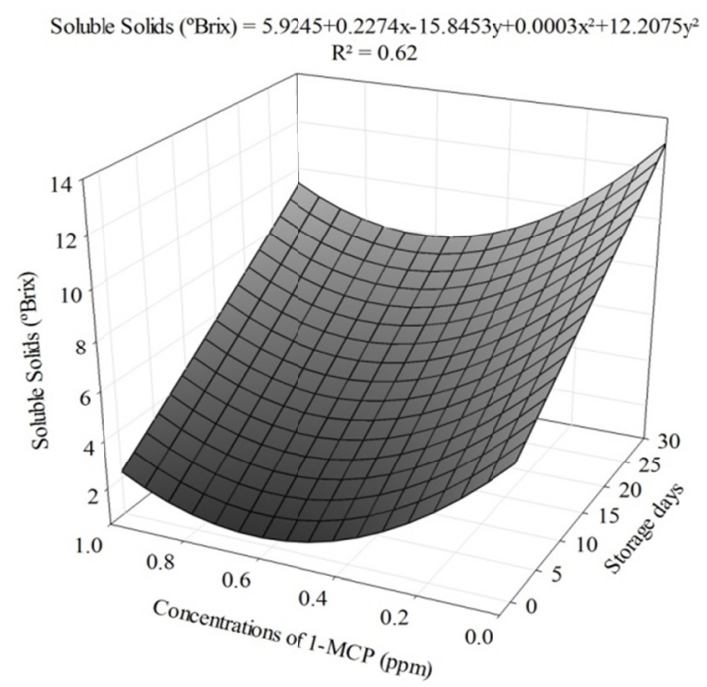

Figure 6. Soluble Solids in 'Prata-Anã' clone Gorutuba banana submitted to different concentrations of 1-MCP and stored at $13 \pm 1{ }^{\circ} \mathrm{C}$ and $85 \pm 5.0 \%$ of UR

For titratable acidity (Figure 7A), a significant interaction was observed for the factors 1-MCP concentration and storage days. Note that the fruit acidity ranged from 0.07 to $0.46 \mathrm{~g}$ a.c. $100 \mathrm{~g}^{-1}$ of pulp. With increasing concentration of 1-MCP the titratable acidity of the fruit tends to reduce to approximately the concentration of 0.6 ppm. However, it was found that as the cold storage days progressed, titratable acidity increased for all concentrations.

The low acidity found in this study is due to the use of 1-MCP which provided delay in fruit ripening and consequently in chemical transformations that occur during the ripening process, giving the fruits more flavor. However, due to the blocking action of 1-MCP on ethylene, the main hormone responsible for fruit ripening, chemical conversion processes were delayed, keeping the fruits green longer.

According to Sarmento (2012), titratable acidity is largely associated with fruit firmness, since cell wall degradation, performed by the action of enzymes, pectinamethylesterase and polygalacturonase, has as its final product the formation of pectic acid and galacturonic acid, increasing thus the titratable acidity of the fruits. Organic acids are used in respiration to produce ATP, resulting in decreased fruit acidity, as well as the respiratory process itself produces organic acids that can accumulate in the fruit, causing a slight increase of the same (Pimentel et al., 2010).

In the Figure $7 \mathrm{~B}$ shows that there was a significant interaction between the factors under study for the $\mathrm{pH}$ parameter, where it is possible to observe that there was a sharp increase in the $\mathrm{pH}$ value up to a concentration of $0.6 \mathrm{ppm}$, followed by a slight reduction up to the concentration of $\mathrm{pH} 1.0 \mathrm{ppm}$. These results predict that 1-MCP acted in retarding the chemical transformations of the fruits. As the storage days progressed, there was a decrease in $\mathrm{pH}$ for all concentrations. In general, in banana pulp the $\mathrm{pH}$ tends to decrease with the fruit ripening, due to the chemical transformations that occur during the ripening process. Almeida et al. (2006), studying the delayed 
ripening of banana apple with the use of 1-MCP, found $\mathrm{pH}$ values ranging between 4,75 and 5,12, and the highest value was found in exposed fruits for 24 hours at 1-MCP.

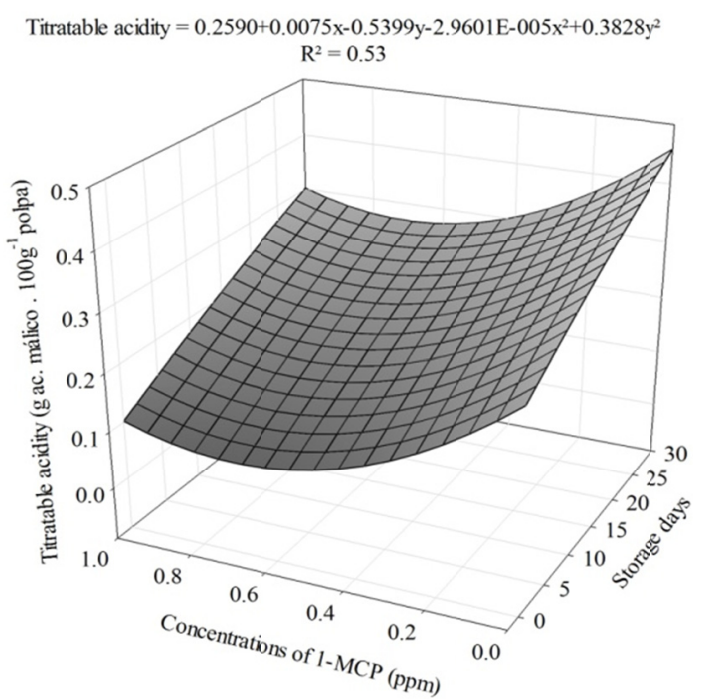

A

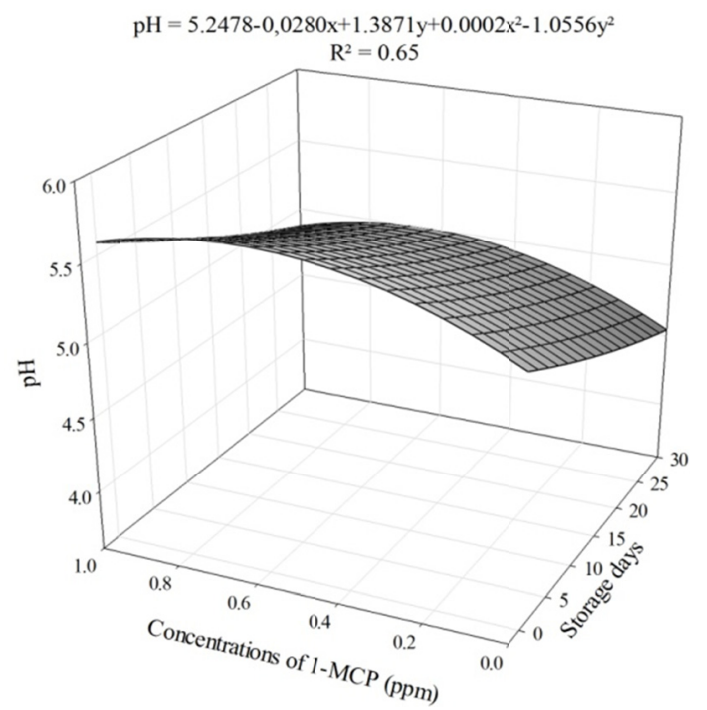

$\mathrm{B}$

Figure 7. Titratable acidity (A), pH (B) in 'Prata-Anã' banana Gorutuba clone subjected to 1-MCP and stored at $13 \pm 1{ }^{\circ} \mathrm{C}$ and $85 \pm 5.0 \%$ of UR

For fruits under refrigerated storage, the effect of 1-MCP on the shelf life of fruits was verified (Table 1), that is, for control fruits, that there was no application of 1-MCP $(0.0 \mathrm{ppm})$. The shelf life was 25 days, where the fruits were in stage 6 of maturation (totally yellow). At 30 days it was verified the beginning of their senescence, the fruits presented with beginning of deterioration, being impossible its commercialization.

For fruits treated with 1-MCP, it is noted the delay in the ripening process, being possible to transport them to more distant markets, with the maritime export, in which 25 days of transport are required. As the destructive analyzes of these fruits were performed, it was not possible to verify the shelf life after this period.

Table 1. Silver Gorutuba banana Shelf Life (VDP) after application of different concentrations of 1-MCP stored under refrigeration at room temperature of $13{ }^{\circ} \mathrm{C}$

\begin{tabular}{lllllllll}
\hline \multirow{2}{*}{ Concentration of 1-MCP $(\mathrm{ppm})$} & \multicolumn{7}{c}{ Days of refrigerated storage after application of 1-MCP } & VDP \\
\cline { 2 - 8 } & 0 & 5 & 10 & 15 & 20 & 25 & 30 & 25 \\
\hline 0.0 & $1 *$ & 1 & 2 & 3 & 5 & 6 & 7 & - \\
0.2 & 1 & 1 & 1 & 2 & 2 & 3 & 5 & - \\
0.4 & 1 & 1 & 1 & 2 & 2 & 2 & 3 & - \\
0.6 & 1 & 1 & 1 & 2 & 2 & 2 & 3 & - \\
0.8 & 1 & 1 & 1 & 2 & 2 & 2 & 3 & - \\
1.0 & 1 & 1 & 1 & 2 & 2 & 2 & 3 & - \\
\hline
\end{tabular}

Note. * Coloring scale CEAGESP (2006).

Shelf life of fruits treated with 1-MCP and kept at room temperature ranged from nine days for concentrations of 0.0 and $0.2 \mathrm{ppm}$ and 21 days for concentrations of 0.4 to $1.0 \mathrm{ppm}$ (Table 2). These results show the efficiency of using 1-MCP to increase the shelf life of fruits, consequently also increasing the time to market.

The efficiency of 1-MCP was also reported by Botrel et al. (2002), analyzing bananas from the cultivar 'Prata-Anã', submitted to 1-MCP and stored at $24{ }^{\circ} \mathrm{C}$ and $78.5 \% \mathrm{RH}$, where they detected positive effect of use of 1-MCP in retarding ripening and extending its useful life. 
Table 2. Shelf Life (VDP) of Gorutuba Silver banana after application of different concentrations of 1-MCP, stored at room temperature of $25^{\circ} \mathrm{C}$

\begin{tabular}{llllllllllll}
\hline \multirow{2}{*}{ Concentration of 1-MCP $(\mathrm{ppm})$} & \multicolumn{1}{c}{ Days after applying of 1-MCP } & \multicolumn{1}{c}{ VDP } \\
\cline { 2 - 11 } & 0 & 3 & 6 & 9 & 12 & 15 & 18 & 21 & 24 & 9 \\
0.0 & $1 *$ & 2 & 3 & 6 & 7 & - & - & - & - & 9 \\
0.2 & 1 & 2 & 2 & 6 & 7 & - & - & - & - & 7 & 21 \\
0.4 & 1 & 1 & 2 & 3 & 3 & 4 & 4 & 6 & 7 & 21 \\
0.6 & 1 & 1 & 2 & 3 & 4 & 4 & 5 & 6 & 7 & 21 \\
0.8 & 1 & 1 & 2 & 3 & 4 & 4 & 5 & 6 & 7 & 21 \\
1.0 & 1 & 1 & 2 & 3 & 3 & 4 & 5 & 6 & 7 & 21 \\
\hline
\end{tabular}

Note. * Coloring scale CEAGESP (2006).

\section{Conclusions}

The use of 1-MCP above $0.4 \mathrm{ppm}$, combined with modified atmosphere and refrigerated storage at $13{ }^{\circ} \mathrm{C}$, delays the process of ripening of 'Prata-Anã' Gorutuba clone's bananas, providing a longer commercialization period.

The use of 1-MCP at a concentration of $0.6 \mathrm{ppm}$ provides firmer fruits, allowing longer transport time.

The use of 1-MCP from $0.4 \mathrm{ppm}$ concentration delayed the ripening of fruits kept at room temperature, providing increase in the shelf life of the fruits.

\section{Acknowledgements}

The authors thank FAPEMIG, CNPq, CAPES and UNIMONTES.

\section{References}

Almeida, G. C., Vilas Boas, E. V. de B., Rodrigues, L. J., \& Paula, N. R. F. de. (2006). Atraso do amadurecimento de banana "Maçã̃" pelo 1-MCP, aplicado previamente à refrigeração. Revista Brasileira de Fruticultura, 28(2), 319-321. https://doi.org/1590/s0100-29452006000200037

Araújo, W. L., Nunes-Nesi, A., Nikoloski, Z., Sweetlove, L. J., \& Fernie, A. R. (2012). Metabolic control and regulation of the tricarboxylic acid cycle in photosynthetic and heterotrophic plant tissues. Plant, Cell \& Environment, 35(1), 1-21. https://doi.org/10.1111/j.1365-3040.2011.02332.x

Baez-Sañudo, M., Siller-Cepeda, J., Muy-Rangel D., \& Heredia, B. (2009). Prolongar o prazo de validade das bananas com 1-metilciclopropeno e um revestimento comestível à base de quitosana. Jornal da Ciência da Alimentação e Agricultura, 89(14), 2343-2349. https://doi.org/10.1002/jsfa.3715

Botrel, N., Freire Junior, M., Vasconcelos, R. M. D., \& Barbosa, H. T. G. (2002). Inibição do amadurecimento da banana-'Prata-Anã' com a aplicação do 1-metilciclopropeno. Revista Brasileira de Fruticultura, 24(1), 53-56. https://doi.org/10.1590/s0100-29452002000100012

Brackmann, A., Steffens, C. A., Sestari, I., Neuwald, D. A., \& Giehl, R. F. H. (2006). Armazenamento em atmosfera modificada e controlada de banana "Prata" com absorção de etileno. Ciência e Agrotecnologia, 30(5), 914-919. https://doi.org/10.1590/s1413-70542006000500014

CEAGESP (Companhia de Entrepostos e Armazéns Gerais de São Paulo). (2006). Normas de Classificação. Retrieved from http://www.ceagesp.gov.br/entrepostos/servicos/produtos/classificacao

Chitarra, M. I. F., \& Chitarra, A. B. (2005). Pós-colheita de frutas e hortaliças: Fisiologia e manuseio (2nd ed.). Lavras: UFLA.

Crispim, J. E., Martins, J. C., Pires, J. C., Rosolem, C. A., \& Cavariani, C. (1994). Determinação da taxa de respiração em sementes de soja pelo método da titulação. Pesquisa Agropecuária Brasileira, 29(10), 1517-1521.

Deliza, R., Castricini, A., Coneglian, R. C. C., \& Polidoro, J. C. (2008). Determinação da taxa respiratória de mamão 'Golden' (Comunicado Técnico 132). Embrapa Agroindústria de Alimentos, Rio de Janeiro.

Hall, A. E., Findell, J. L., Schaller, G. E., Sisler, E. C., \& Bleecker, A. B. (2000). Ethylene Perception by the ERS1 Protein in Arabidopsis. Plant Physiology, 123(4), 1449-1458. https://doi.org/10.1104/pp.123.4.1449

Instituto Adolfo Lutz. (2008). Método Físico Químicos para Análise de Alimentos (6th ed.). São Paulo, Brazil. 
Kader, A. A. (1992). Postharvest Technology of Horticultural Crops. University of California, California.

Lana, M. M., \& Finger, F. L. (2000). Atmosfera modificada e controlada: Aplicação na conservação de produtos hortícolas. EMBRAPA Comunicação Para Transferência de Tecnologia/EMBRAPA Hortaliças, Brasília.

Li, J., Lei, H., Song, H., Lai, T., Xu, X., \& Shi, X. (2017). 1-methylcyclopropene (1-MCP) suppressed postharvest blue mold of apple fruit by inhibiting the growth of Penicillium expansum. Postharvest Biology and Technology, 125, 59-64. https://doi.org/10.1016/j.postharvbio.2016.11.005

Ohashi, T. L., Foukaraki, S., Corrêa, D. S., Ferreira, M. D., \& Terry, L. (2016). Influence of 1-methylcyclopropene on the biochemical response and ripening of "solo" papayas. Revista Brasileira de Fruticultura, 38(2). https://doi.org/10.1590/0100-29452016791

Pimentel, R. M. de A., Guimarães, F. N., Santos, V. M. dos, \& Resende, J. C. F. de. (2010). Qualidade pós-colheita dos genótipos de banana PA42-44 e Prata-Anã cultivados no norte de Minas Gerais. Revista Brasileira de Fruticultura, 32(2), 407-413. https://doi.org/10.1590/s0100-29452010005000047

Pinheiro, A. C. M., Vilas Boas, E. V. de B., Alves, A. de P., \& La Selva, M. (2007). Amadurecimento de bananas "maçã" submetidas ao 1-metilciclopropeno (1-MCP). Revista Brasileira de Fruticultura, 29(1), 1-4. https://doi.org/10.1590/s0100-29452007000100003

Santos, A. E. O., Assis, J. S., Batista, P. F., \& Santos, O. O. (2011). Utilização de atmosfera modificada na alimentação pós-colheita de mangas 'Tommy Atkins'. Revista Semiárido De Visu, 1(1), 10-17.

Sarmento, C. A. R. (2012). Determinação do ponto de colheita e a avaliação da pós-colheita de banana princesa utilizando biofilme (Dissertação de Mestrado, Universidade Federal de Sergipe, Sergipe, Brazil).

Silva, C. S., Lima, L. C., Santos, H. S., Camili, E. C., Vieira, C. R. Y. I., Martin, C. S., \& Vieites, R. L. (2006). Amadurecimento da banana-prata climatizada em diferentes dias após a colheita. Ciência e Agrotecnologia, 30(1), 103-111. https://doi.org/10.1590/S1413-70542006000100015

Silva, C. S., Lima, L. C., Santos, H. S., Camili, E. C., Vieira, C. R. Y. I., Martin, C. da S., \& Vieites, R. L. (2006). Amadurecimento de banana-prata climatizada em diferentes dias após a colheita. Ciência e Agrotecnologia, 30(1), 103-111. https://doi.org/10.1590/S1413-70542006000100015

Watkins C. B. (2006). The use of 1-methylcyclopropene (1-MCP) on fruits and vegetables. Biotechnology Advances, 24(4), 389-409. https://doi.org/10.1016/j.biotechadv.2006.01.005

Yan, S., Chen, J., Yu, W., Kuang, J., Chen, W., Li, X., \& Lu, W. (2010). Expression of genes associated with ethylene-signalling pathway in harvested banana fruit in response to temperature and 1-MCP treatment. Journal of the Science of Food and Agriculture, 91(4), 650-657. https://doi.org/10.1002/jsfa.4226

\section{Copyrights}

Copyright for this article is retained by the author(s), with first publication rights granted to the journal.

This is an open-access article distributed under the terms and conditions of the Creative Commons Attribution license (http://creativecommons.org/licenses/by/4.0/). 